\title{
Abnormalities in ileal stem, neurogenin 3, and enteroendocrine cells in patients with irritable bowel syndrome
}

\author{
Magdy El-Salhy ${ }^{1,2,3^{*}}$ and Odd Helge Gilja $2,3,4$
}

\begin{abstract}
Background: This study examined whether the densities of stem- and enteroendocrine cell progenitors are abnormal in the ileum of patients with irritable bowel syndrome (IBS), and whether any abnormalities in ileal enteroendocrine cells are correlated with abnormalities in stem cells and enteroendocrine cell progenitors.

Methods: One hundred and one IBS patients covering all IBS subtypes were recruited, and 39 non-IBS subjects were included as a control group. The patients and controls underwent standard colonoscopies, during which biopsy specimens were obtained from the ileum. The biopsy specimens were stained with hematoxylin-eosin and immunostained for Musashi-1 (Msi-1), neurogenin 3 (NEUROG3), chromogranin A (CgA), serotonin, peptide YY (PYY), oxyntomodulin (enteroglucagon), pancreatic polypeptide, and somatostatin. The immunoreactive cells were quantified by computerized image analysis.

Results: The densities of Msi-1, NEUROG3, CgA, and serotonin cells were reduced in all IBS patients and in patients with diarrhea-predominant IBS (IBS-D), mixed-diarrhea-and-constipation IBS (IBS-M), and constipation-predominant (IBS-C) relative to the control subjects. While the PYY cell density was increased in IBS-C relative to controls, it did not differ between control subjects and IBS-D and IBS-M patients. The densities of Msi-1 and NEUROG3 cells were strongly correlated with that of CgA cells.

Conclusions: The abnormalities in the ileal enteroendocrine cells appear to be caused by two mechanisms: (1) decreases in the clonogenic activity of the stem cells and in the endocrine-cell progenitors differentiating into enteroendocrine cells, and (2) switching on the expression of PYY and switching off the expression of certain other hormones in other types of the enteroendocrine cells.
\end{abstract}

Keywords: Enteroendocrine cells, IBS, Ileum, Immunohistochemistry, Mushasi-1, Neurogenin 3, PYY, Serotonin

\section{Background}

Irritable bowel syndrome (IBS) is a chronic gastrointestinal condition with a prevalence of $5-20 \%$ of the world adult population [1-9]. IBS is reportedly also present in in about $50 \%$ of patients with ulcerative colitis patients and Crohn's disease in remission [10, 11]. Furthermore, $38 \%$ of patients with celiac disease suffer from IBS symptoms despite consuming a gluten-free diet [12].

\footnotetext{
* Correspondence: magdy.el-salhy@helse-fonna.no; magdy.elsalhy@helse-fonna.no

${ }^{1}$ Section for Gastroenterology, Department of Medicine, Stord Helse-Fonna Hospital, Box 4000, 5409 Stord, Stord, Norway

${ }^{2}$ Section for Gastroenterology, Department of Clinical Medicine, University of Bergen, Bergen, Norway

Full list of author information is available at the end of the article
}

The etiology of IBS is unclear, but certain factors appear to play a pivotal role in its pathophysiology, including genetic factors, intestinal bacterial flora, diet, and chronic low-grade intestinal inflammation [13, 14]. Abnormally low densities of endocrine cells in the stomach, duodenum, ileum, colon, and rectum have been reported in patients with IBS [15-29], which could explain the dysmotility, visceral hypersensitivity, and abnormal secretion seen in IBS patients [30]. These observations have prompted suggestions that the abnormalities in the gut endocrine cells play a significant role in the pathophysiology of IBS $[13,14]$.

Musashi-1 (Msi-1) is localized in gastrointestinal stem cells and their early progenitors, and neurogenin 3 
Table 1 Primary antibodies used for immunohistochemical staining

\begin{tabular}{|c|c|c|c|c|}
\hline Antibody target & Source & Code number & Working dilution & Type of antibody \\
\hline$\overline{M s i-1}$ & Novus Biologicals Europe (Abingdon, UK) & NB100-1759 & 1:100 & $\begin{array}{l}\text { Polyclonal, raised in rabbit against residues } \\
5-21 \text { [APQPGLASPDSPHDPCK] of human, } \\
\text { mouse, and rat Msi-1 }\end{array}$ \\
\hline NEUROG3 & ThermoFisher Scientific (Oslo, Norway) & BT-B56180 & $1: 50$ & $\begin{array}{l}\text { Polyclonal, raised in rabbit against } \\
\text { KLH-conjugated synthetic peptide at } \\
40-69 \text { amino acids from the } \\
\text { N-terminal region of human NEUROG3 }\end{array}$ \\
\hline $\mathrm{CgA}$ & Dako (Glostrup, Denmark) & M869 & 1:1000 & $\begin{array}{l}\text { Monoclonal, raised in mouse against the } \\
\text { N-terminal of purified CgA }\end{array}$ \\
\hline Serotonin & Dako & 5HT-209 & $1: 1500$ & $\begin{array}{l}\text { Monoclonal, raised in mouse against } \\
\text { serotonin }\end{array}$ \\
\hline PYY & Alpha-Diagnostica (San Antonio, TX, USA) & PYY 11A & 1:1000 & Polyclonal, raised in rabbit against PYY \\
\hline $\begin{array}{l}\text { Oxyntomodulin } \\
\text { (enteroglucagon) }\end{array}$ & Acris Antibodies (Herford, Germany) & BP508 & 1:800 & $\begin{array}{l}\text { Polyclonal, raised in rabbit against porcine } \\
\text { glicentin/glucagon }\end{array}$ \\
\hline PP & Diagnostic Biosystems (Pleasanton, CA, USA) & $\# 114$ & $1: 400$ & $\begin{array}{l}\text { Polyclonal, raised in rabbit against synthetic } \\
\text { human PP }\end{array}$ \\
\hline Somatostatin & Dako & A566 & 1:200 & $\begin{array}{l}\text { Polyclonal, raised in rabbit against synthetic } \\
\text { human somatostatin }\end{array}$ \\
\hline
\end{tabular}

(NEUROG3) is a marker for early intestinal endocrinecell progenitors [31-33]. It has been reported recently that the densities of Msi-1 and NEUROG3 cells are reduced in the duodenum of patients with IBS, with these decreases being associated with reductions in duodenal endocrine cells, which could in turn be caused by decreases in stem cells and their proliferation progeny into endocrine cells [34].

The types and densities of endocrine cells differ between the distal and proximal parts of the small intestine, which is probably due to the quite different functions of these two sections of the gastrointestinal tract $[35,36]$. Whereas the proximal small intestine contains serotonin, secretin, cholecystokinin, gastric inhibitory polypeptide (GIP), and somatostatin cells, the distal small intestine contains serotonin, peptide YY (PYY), pancreatic polypeptide (PP), oxyntomodulin (enteroglucagon), and somatostatin cells [35, 36].

This study aimed at examining whether the densities of stem- and endocrine-cell progenitors as manifested by Msi-1 and NEUROG3 are affected in the ileum of patients with IBS. Furthermore, the densities of ileal endocrine cells were measured with the aim of establishing their correlation with possible abnormalities in stemand endocrine-cell progenitors.

\section{Methods}

\section{Patients and controls}

One hundred and one patients with IBS according to Rome III criteria [37, 38] were recruited at Stord Hospital, Stord, Norway. These patients comprised 80 females and 21 males with a mean age of 40 years (age range 1865 years). Thirty-five of the patients had diarrheapredominant IBS (IBS-D), 34 had mixed-diarrhea-andconstipation IBS (IBS-M), and 32 had constipationpredominant IBS (IBS-C). The IBS symptoms had been present in all of the patients for many years, and their onset was not identified as being associated with gastrointestinal infection. All of the patients underwent a physical examination and were investigated by blood tests to exclude inflammatory, endocrine, liver, kidney, and systemic diseases. Furthermore, celiac disease was excluded by performing histopathological examinations of duodenal biopsy samples obtained during gastroscopy.

Table 2 Densities of immunoreactive cells in control subjects, IBS-total patients, and IBSsubtype patients

\begin{tabular}{llllll}
\hline Cell type & Controls & IBS-total & IBS-D & IBS-M & IBS-C \\
\hline Msi-1 & $6.2 \pm 0.2$ & $4.8 \pm 0.2^{* * *}$ & $4.3 \pm 0.3^{* * *}$ & $4.8 \pm 0.2^{* *}$ & $5.1 \pm 0.2^{*}$ \\
NEUROG3 & $16.8 \pm 0.8$ & $7.6 \pm 0.3^{* * *}$ & $8.0 \pm 0.6^{* * *}$ & $6.7 \pm 0.5^{* * *}$ & $3.1 \pm 0.7^{* * *}$ \\
CgA & $64.3 \pm 3.6$ & $28.8 \pm 2.1^{* * *}$ & $29.2 \pm 3.5^{* * *}$ & $25.7 \pm 3.6^{* * *}$ & $30.3 \pm 3.7^{* * *}$ \\
Serotonin & $40.8 \pm 3.5$ & $12.0 \pm 1.3^{* * *}$ & $10.7 \pm 2.0^{* * *}$ & $11.1 \pm 2.0^{* * *}$ & $13.9 \pm 2.5^{* * *}$ \\
PYY & $26.6 \pm 1.6$ & $33.5 \pm 1.4^{*}$ & $27.6 \pm 1.4$ & $33.5 \pm 2.4$ & $41.9 \pm 2.3^{* *}$ \\
\hline
\end{tabular}

${ }^{*} P<0.05,{ }^{* *} P<0.01,{ }^{* * *} P<0.001$ vs. controls (Dunn's multiple-comparisons test) 
A control group was included that comprised 39 nonIBS subjects (27 females and 12 males; mean age 38 years, age range 18-64 years) who had undergone colonoscopies because of (1) gastrointestinal bleeding that was found to be due to hemorrhoids $(n=24)$ or angiodysplasia $(n=3)$, or (2) health worries resulting from a relative being diagnosed with colon carcinoma $(n=12)$.

The study was performed in accordance with the Declaration of Helsinki and was approved by the
Regional Committee for Medical and Health Research Ethics West, Bergen, Norway. All subjects gave both oral and written consents to participate.

Colonoscopy, histopathology, and immunohistochemistry A standard colonoscopy was performed on both the patients and controls, with segmental biopsy specimens taken from the colon and rectum, and four biopsy samples taken from the ileum of each subject. The biopsy
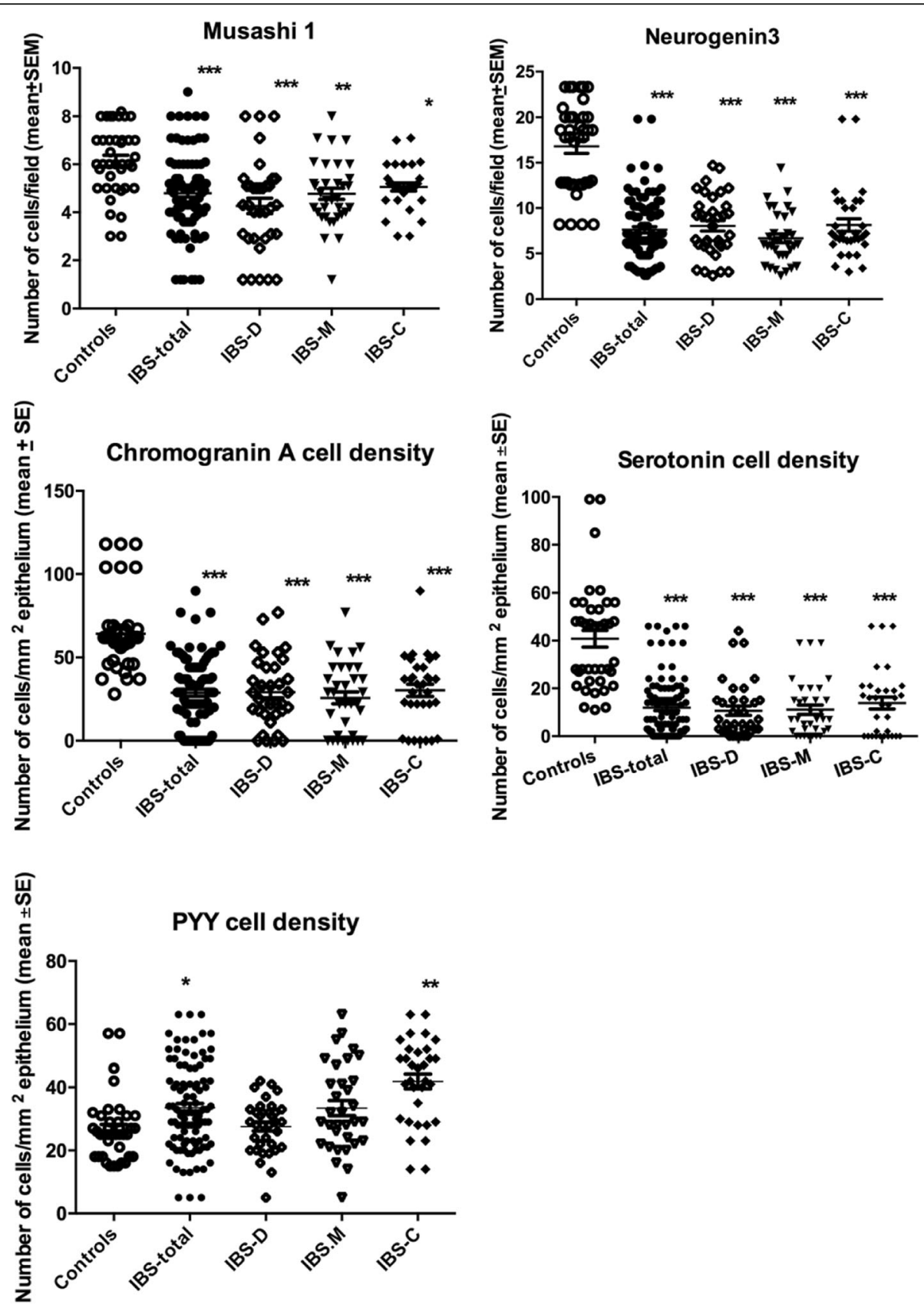

Fig. 1 Densities of Msi-1, NEUROG3, CgA, serotonin, and PYY cells in the ileum of control subjects and IBS-total, IBS-D, IBS-M, and IBS-C patients. ${ }^{*} P<0.05,{ }^{* *} P<0.01$, and ${ }^{* *} P<0.001$ vs. controls (Dunn's multiple-comparisons test) 


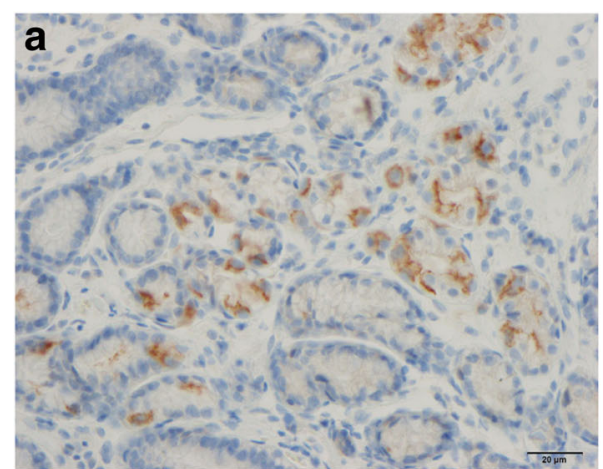

Fig. 2 Ileal Msi-1 cells in a control subject (a) and an IBS patient (b)

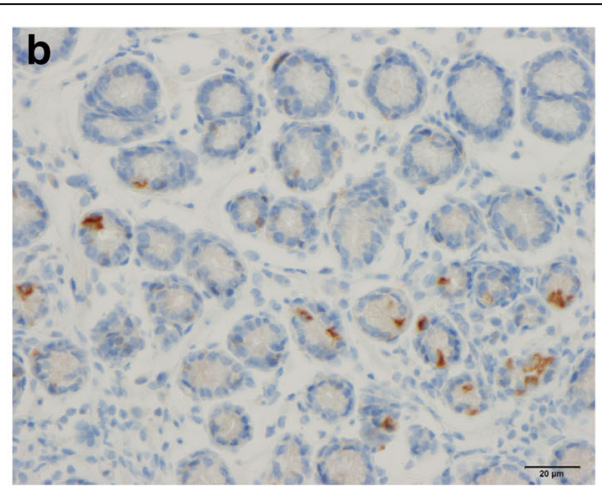

each frame (field) on the monitor representing a tissue area of $0.14 \mathrm{~mm}^{2}$. The density of endocrine cells was expressed as the number of endocrine cells per square millimeter of epithelium, the density of Msi-1 cells was expressed as the number of immunoreactive cells per crypt, and the density of NEUROG3 cells was expressed as the number of immunoreactive cells per field. Quantification was performed in ten randomly chosen microscopic fields. The measurements were made by the same person (M.E-S.) who was blind to the identities of the slides.

\section{Statistical analysis}

Differences in the sex and age distributions between patients and controls were tested using Fisher's exact test and the Mann-Whitney nonparametric test, respectively. Differences between control subjects, all IBS patients (IBS-total), and IBS-D, IBS-M, and IBS-C patients were tested using the Kruskal-Wallis nonparametric test with Dunn's posttest. The Kruskal-Wallis test is a nonparametric test that compares three or more unmatched groups, while Dunn's multiple-comparisons test compares the difference in the sum of ranks between two columns with the expected average difference.

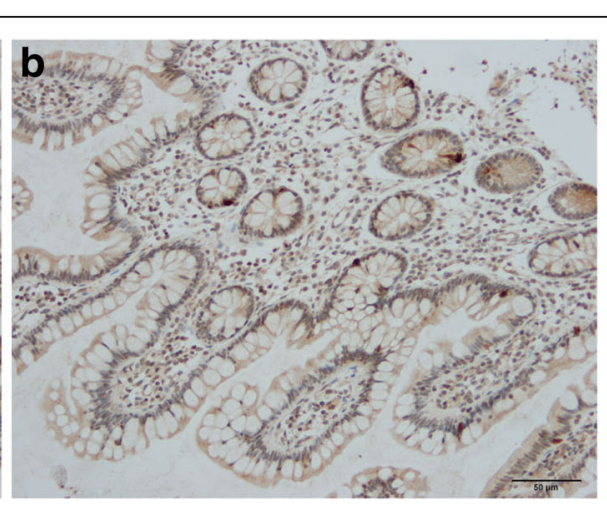

Fig. 3 lleal NEUROG3 cells in a control subject (a) and an IBS patient (b) 

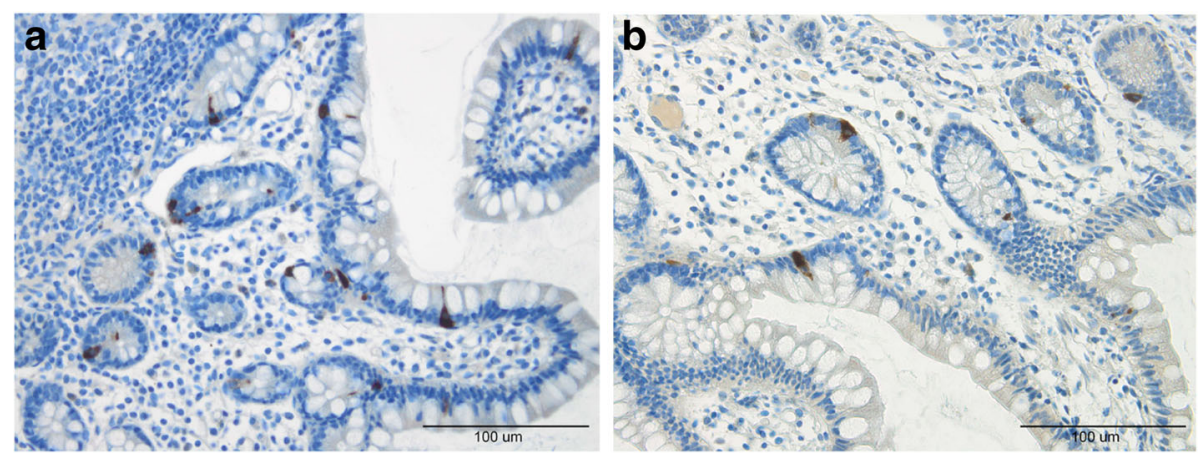

Fig. 4 lleal CgA cells in a control subject (a) and a patient with IBS (b)

Correlations were assessed using the Spearman nonparametric test. The data are presented as mean \pm SEM values, and differences for which $P<0.05$ were considered to be statistically significant.

\section{Results}

Sex and age characteristics of patients and controls The sex and age distributions did not differ significantly between the patients and controls $(P=0.27$ and $P=0.67$, respectively).

\section{Endoscopy, histopathology, and immunohistochemistry}

The ileum, colon, and rectum of both the patients and control subjects were macroscopically normal. The findings of histopathological examinations of the ileum, colon, and rectum were also normal in both the patients and controls.

Cells that were immunoreactive for Msi-1, NEUROG3, chromogranin A (CgA), serotonin, PYY, PP, oxyntomodulin (enteroglucagon), and somatostatin were found in the ileum of all of the subjects (i.e., both patients and controls), mostly in the crypts. These cells were basketor flask-shaped, and sometimes had a basal cytoplasmic process.

\section{Computerized image analysis}

The densities of Msi-1, NEUROG3, CgA, serotonin, and PYY cells are summarized in Table 2 and illustrated in Figs. 1, 2, 3, 4, 5 and 6. Few of the cells in the examined biopsy material were immunoreactive for PP, enteroglucagon, or somatostatin, which made it impossible to reliably quantify these types of cells.

The Msi-1 cell density was significantly lower in IBStotal, IBS-D, IBS-M, and IBS-C patients than in the control subjects $(P<0.001, P<0.001, P<0.01$, and $P<0.05$, respectively). Dunn's posttest showed that the NEUROG3 cell density was lower in IBS-total, IBS-D, IBS-M, and IBS-C patients than in the controls $(P<0.001$ for all $)$.

The Kruskal-Wallis nonparametric test showed significant differences in the $\mathrm{CgA}$ and serotonin cell densities between control subjects, IBS-total patients, and IBS-subtype patients $(P<0.0001$ for both cell types). The CgA and serotonin cell densities were lower in IBS-total, IBS-D, IBS-M, and IBS-C patients than in controls $(P<0.001$ for both cell types). The Kruskal-Wallis test revealed significant differences in PYY cell density between controls and IBS-total, IBSD, IBS-M, and IBS-C patients $(P<0.0001$ for all $)$.

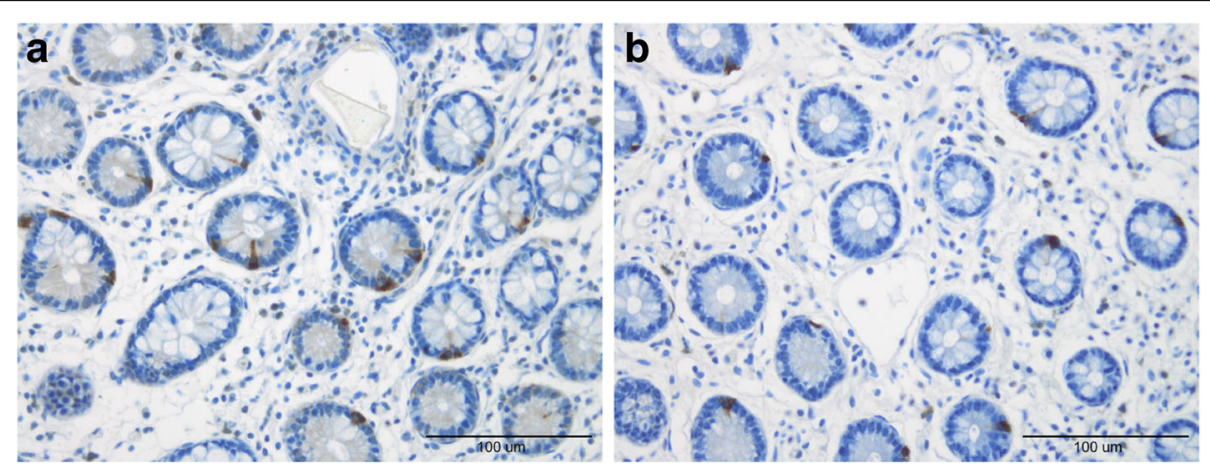

Fig. 5 lleal serotonin cells in a control subject (a) and a patient with IBS (b) 

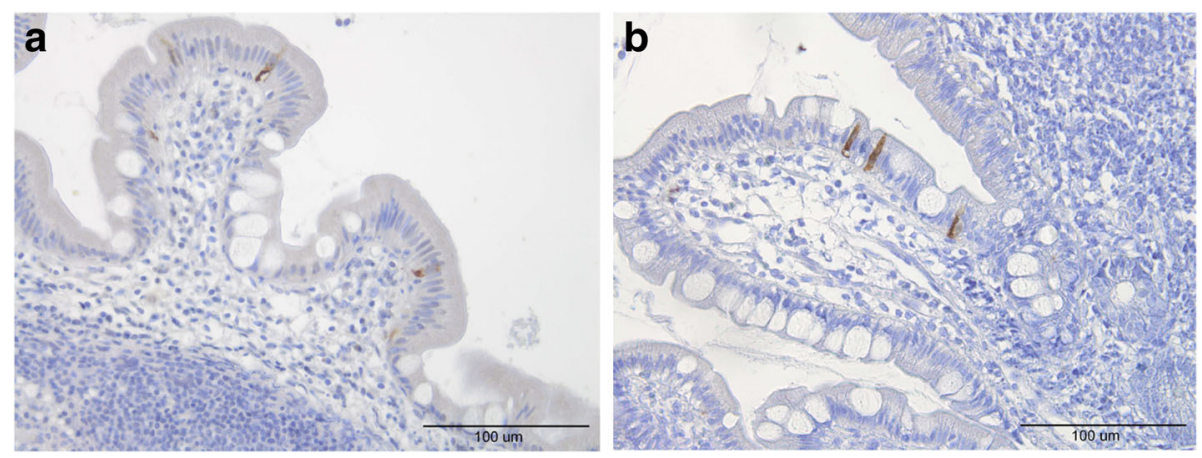

Fig. 6 lleal PYY cells in a control subject (a) and a patient with IBS-C (b)

Dunn's posttest showed that the PYY cell density was significantly higher in IBS-total and IBS-C patients than in the control subjects $(P<0.02$ and $P<0.01$, respectively), while it did not differ significantly between IBS-D and IBS-M patients and the control subjects $(P=0.2$ and $P=0.5$, respectively).

The densities of Msi-1 and NEUROG3 cells were strongly correlated with that of CgA cells $(P<0.0001$ and $r=0.47$, and $P<0.0001$ and $r=0.40$, respectively) (Fig. 7).

\section{Discussion}

Each crypt in the intestine contains four to six stem cells. Stem cells either divide into 2 new stem cells (clonogeny) or differentiate into mucosal epithelial cells (differentiation progeny) [33, 39-52]. The stem cell differentiation comprises two lineages: secretory and absorptive. The secretory lineage ends to goblet, endocrine, and Paneth cells, and the absorptive lineage leads to absorptive enterocytes [33, 39-52]. Msi-1 occurs in both intestinal stem cells and early progenitors [33, 53-55], while NEUROG3 is localized in intestinal endocrine-cell progenitors [32, 56, 57]. In the present study the densities of both Msi-1 and NEUROG3 cells in the ileum were lower in patients with IBS than in controls, which is similar to previous findings in the proximal small intestine [34].

$\mathrm{CgA}$ occurs in all types of enteroendocrine cells [58-60], with CgA cells density reflecting the total density of the ileal endocrine cells. Similar to the situation in the proximal small intestine [34], the CgA cells density in the ileum was reduced in the present IBS patients, which is consistent with previous observations that we have made in another cohort of patients [61]. The reduction in CgA cell density observed herein was significantly correlated with the reductions in Msi-1 and NEUROG3 cells. A reduction in NEUROG3 was associated with a decrease in the number of intestinal endocrine cells in patients with congenital malabsorptive diarrhea [31], in patients with smallintestine allograft rejection [32], and in NEUROG3knockout mice [62]. It is tempting to speculate that the decreased density of ileal endocrine cells observed in the present IBS patients is caused by the reductions in Msi-1 and NEUROG3 cells.

Serotonin cells are the main endocrine cell type in the ileum [36]. The decreased cell density of CgA cell density found here and in our previous cohort of IBS patients [29] may be caused by the decreases in the serotonin cell density. Serotonin stimulates small-, and large intestine
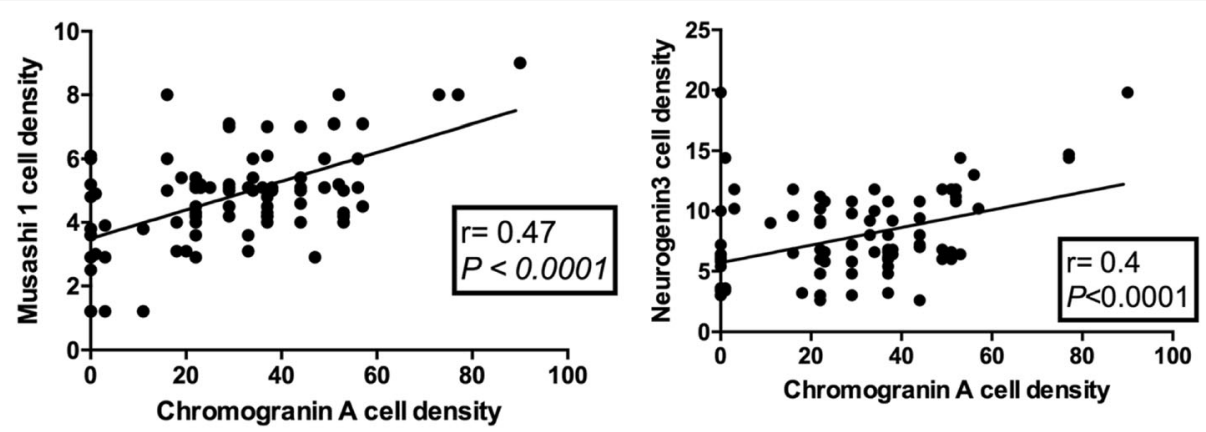

Fig. 7 Correlations between the density of CgA cells and the densities of Msi-1 and NEUROG3 cells (Spearman nonparametric test) 
motility, and activates the submucosal enteric nervous system that transports sensation from the gastrointestinal tract to the central nervous system [30].

While the density of ileal PYY cells was similar to the control subjects in the IBS-D and IBS-M patients, it was higher in IBS-C patients, which is consistent with previously results obtained in another cohort of IBS patients [29]. It is well known that enteroendocrine cell can express two hormones, such as glucagon-like peptide-1 and GIP in the small intestine, and PYY and oxyntomodulin in the distal small and large intestines [63-65]. It has been shown further that mature enteroendocrine cells are able of synthetize up to seven different hormones [66-68]. The increase in the density of PYY cells in IBS-C is probably caused by switching off the expression of other hormones and switching on the expression of PYY. PYY regulates the so-called ileal brake and increases the absorption of water and electrolytes [69-74]. It also inhibits vasoactive intestinal polypeptide and prostaglandin E2, both of which stimulate intestinal fluid secretion [75-77]. It is possible that the increase in the PYY cell density in IBS-C patients would slow the intestinal transit by strengthening the ileal brake, increasing the absorption of water, and decreasing the secretion of the intestinal fluid, and thereby also result in constipation.

It is difficult to conclude whether the changes in stem and enteroendocrine cells observed in here are primary or secondary to IBS. However, it was hypothesized recently that factors known to play a part in the pathophysiology of IBS-including genetics, diet, the intestinal microbiome, and low-grade inflammation-exert their effects by acting on stem cells and differentiation progeny toward enteroendocrine cells [78]. In other words, the changes found in the present study are believed to be caused by other factors engaged in the pathophysiology of IBS.

\section{Conclusion}

The present study confirms the finding of a previous study involving another cohort of IBS patients that the density of enteroendocrine cells is reduced in the ileum [36]. This reduction in the enteroendocrine cells seems to be caused by decreases in the clonogenic activity of the stem cell and in the differentiation into enteroendocrine cells from stem-cell progenitors. The changes in the proportions of the endocrine cell types appear to result from switching on and switching off the expressions of certain hormones by the enteroendocrine cells [66-68].

\section{Abbreviations}

CgA: Chromogranin A; GIP: Gastric inhibitory polypeptide; IBS: Irritable bowel syndrome; IBS-C: Constipation-predominant IBS; IBS-D: Diarrhea-predominant IBS; IBS-M: Mixed-diarrhea-and-constipation IBS; Msi-1: Musashi-1; NEUROG3: Neurogenin 3; PP: Pancreatic polypeptide; PYY: Peptide YY

\section{Acknowledgements}

Not applicable.

\section{Funding}

This study was supported by grants from Helse-Vest, Norway (grant no. 911978) and Helse-Fonna (grant no. 40415).

\section{Availability of data and materials}

All data generated or analyzed during the study are included in this article. The subjects included in the study were assigned a code, and all data were kept in a secure database to maintain anonymity. Relevant raw data from this study can be provided upon reasonable request to the authors.

\section{Authors' contributions}

ME-S designed the study, performed the research, analyzed the results, and wrote the manuscript; OHG contributed to the study design and the analysis of the results, and commented on the manuscript. Both authors have approved the submitted version of the manuscript.

\section{Ethics approval and consent to participate}

The study was approved by the Regional Committee for Medical and Health Research Ethics West, Bergen, Norway. All subjects gave both oral and written consents to participate.

\section{Consent for publication}

Not applicable.

\section{Competing interests}

The authors declare that they have no competing interests.

\section{Publisher's Note}

Springer Nature remains neutral with regard to jurisdictional claims in published maps and institutional affiliations.

\section{Author details}

'Section for Gastroenterology, Department of Medicine, Stord Helse-Fonna Hospital, Box 4000, 5409 Stord, Stord, Norway. ${ }^{2}$ Section for Gastroenterology, Department of Clinical Medicine, University of Bergen, Bergen, Norway. ${ }^{3}$ National Centre for Functional Gastrointestinal Disorders, Department of Medicine, Haukeland University Hospital, Bergen, Norway. ${ }^{4}$ National Centre for Ultrasound in Gastroenterology, Department of Medicine, Haukeland University Hospital, Bergen, Norway.

Received: 3 January 2017 Accepted: 29 June 2017

Published online: 01 August 2017

\section{References}

1. Thompson WG: A world view of IBS In: Irritable bowel syndrome: diagnosis and treatment. edn. Edited by Camilleri M, Spiller RC. Philadelphia and London: Saunders; 2002;17-26.

2. Drossman DA, Li Z, Andruzzi E, Temple RD, Talley NJ, Thompson WG, Whitehead WE, Janssens J, Funch-Jensen P, Corazziari E, et al. U.S. householder survey of functional gastrointestinal disorders. Prevalence, sociodemography, and health impact. Dig Dis Sci. 1993;38:1569-80.

3. El-Salhy M, Gundersen D, Hatlebakk JG, Hausken T. Irritable bowel syndrome: diagnosis, pathogenesis and treatment options. New York: Nova Science Publishers, Inc.; 2012.

4. Ford AC, Vandvik PO. Irritable bowel syndrome. Clin Evid (Online). 2012;2012

5. Quigley EM, Locke GR, Mueller-Lissner S, Paulo LG, Tytgat GN, Helfrich I, Schaefer E. Prevalence and management of abdominal cramping and pain: a multinational survey. Aliment Pharmacol Ther. 2006;24:411-9.

6. Vandvik PO, Lydersen S, Farup PG. Prevalence, comorbidity and impact of irritable bowel syndrome in Norway. Scand J Gastroenterol. 2006;41:650-6.

7. Saito YA, Schoenfeld P, Locke GR 3rd. The epidemiology of irritable bowel syndrome in North America: a systematic review. Am J Gastroenterol. 2002:97:1910-5

8. Dakin CL, Small CJ, Batterham RL, Neary NM, Cohen MA, Patterson M, Ghatei MA, Bloom SR. Peripheral oxyntomodulin reduces food intake and body weight gain in rats. Endocrinology. 2004;145:2687-95.

9. Lovell RM, Ford AC. Global prevalence of and risk factors for irritable bowel syndrome: a meta-analysis. Clin Gastroenterol Hepatol. 2012;10:712-21. e714 
10. El-Salhy M, Gundersen D, Gilja OH, Hatlebakk JG, Hausken T. Is irritable bowel syndrome an organic disorder? World J Gastroenterol. 2014;2:384-400.

11. El-Salhy M. Recent advances in the diagnosis of irritable bowel syndrome. Expert Rev Gastroenterol Hepatol. 2015;9:1161-74.

12. Sainsbury A, Sanders DS, Ford AC: Prevalence of irritable bowel syndrometype symptoms in patients with celiac disease: a meta-analysis. Clin Gastroenterol Hepatol 2013;11:359-365 e351qqq.

13. El-Salhy M. Recent developments in the pathophysiology of irritable bowel syndrome. World J Gastroenterol. 2015;21:7621-36.

14. El-Salhy M. Irritable bowel syndrome: diagnosis and pathogenesis. World J Gastroenterol. 2012;18:5151-63.

15. El-Salhy M, Lillebo E, Reinemo A, Salmelid L. Ghrelin in patients with irritable bowel syndrome. Int J Mol Med. 2009;23:703-7.

16. Dizdar V, Spiller R, Singh G, Hanevik K, Gilja OH, El-Salhy M, Hausken T. Relative importance of abnormalities of CCK and 5-HT (serotonin) in giardiainduced post-infectious irritable bowel syndrome and functional dyspepsia. Aliment Pharmacol Ther. 2010;31:883-91.

17. El-Salhy M, Vaali K, Dizdar V, Hausken T. Abnormal small-intestinal endocrine cells in patients with irritable bowel syndrome. Dig Dis Sci. 2010;55:3508-13.

18. El-Salhy M, Gundersen D, Ostgaard H, Lomholt-Beck B, Hatlebakk JG, Hausken T. Low densities of serotonin and peptide $Y Y$ cells in the colon of patients with irritable bowel syndrome. Dig Dis Sci. 2012;57:873-8.

19. El-Salhy M, Gundersen D, Hatlebakk JG, Hausken T. Abnormal rectal endocrine cells in patients with irritable bowel syndrome. Regul Pep. 2014;188:60-5.

20. Coates MD, Mahoney CR, Linden DR, Sampson JE, Chen J, Blaszyk H, Crowell MD, Sharkey KA, Gershon MD, Mawe GM, et al. Molecular defects in mucosal serotonin content and decreased serotonin reuptake transporter in ulcerative colitis and irritable bowel syndrome. Gastroenterology. 2004;126:1657-64.

21. Wang SH, Dong L, Luo JY, Gong J, Li L, Lu XL, Han SP. Decreased expression of serotonin in the jejunum and increased numbers of mast cells in the terminal ileum in patients with irritable bowel syndrome. World J Gastroenterol. 2007;13:6041-7.

22. Lee KJ, Kim YB, Kim JH, Kwon HC, Kim DK, Cho SW. The alteration of enterochromaffin cell, mast cell, and lamina propria T lymphocyte numbers in irritable bowel syndrome and its relationship with psychological factors. J Gastroenterol Hepatol. 2008;23:1689-94.

23. Park JH, Rhee PL, Kim G, Lee JH, Kim YH, Kim JJ, Rhee JC, Song SY. Enteroendocrine cell counts correlate with visceral hypersensitivity in patients with diarrhoea-predominant irritable bowel syndrome. Neurogastroenterol Motil. 2006;18:539-46.

24. Kim HS, Lim JH, Park H, Lee SI. Increased immunoendocrine cells in intestinal mucosa of postinfectious irritable bowel syndrome patients 3 years after acute Shigella infection-an observation in a small case control study. Yonsei Med J. 2010;51:45-51.

25. Dunlop SP, Coleman NS, Blackshaw E, Perkins AC, Singh G, Marsden CA, Spiller RC. Abnormalities of 5-hydroxytryptamine metabolism in irritable bowel syndrome. Clin Gastroenterol Hepatol. 2005;3:349-57.

26. Spiller RC, Jenkins D, Thornley JP, Hebden JM, Wright T, Skinner M, Neal KR. Increased rectal mucosal enteroendocrine cells, T lymphocytes, and increased gut permeability following acute campylobacter enteritis and in post-dysenteric irritable bowel syndrome. Gut. 2000;47:804-11.

27. El-Salhy M, Lomholt-Beck B, Hausken T. Chromogranin a as a possible tool in the diagnosis of irritable bowel syndrome. Scand J Gastroenterol. 2010;45:1435-9.

28. El-Salhy M, Mazzawi T, Gundersen D, Hausken T. Chromogranin a cell density in the rectum of patients with irritable bowel syndrome. Mol Med Report. 2012;6:1223-5.

29. El-Salhy M, Gilja OH, Gundersen D, Hatlebakk JG, Hausken T. Endocrine cells in the ileum of patients with irritable bowel syndrome. World J Gastroenterol. 2014;20:2383-91

30. El-Salhy M, Gundersen D, Gilja OH, Hatlebakk JG, Hausken T. Is irritable bowel syndrome an organic disorder? World J Gastroenterol. 2014;20:384-400.

31. Wang J, Cortina G, Wu SV, Tran R, Cho JH, Tsai MJ, Bailey TJ, Jamrich M, Ament ME, Treem WR, et al. Mutant neurogenin-3 in congenital malabsorptive diarrhea. N Engl J Med. 2006;355:270-80.

32. Fishbein TM, Novitskiy G, Lough DM, Matsumoto C, Kaufman SS, Shetty K, Zasloff M. Rejection reversibly alters enteroendocrine cell renewal in the transplanted small intestine. Am J Transplant. 2009;9:1620-8.
33. Montgomery RK, Breault DT. Small intestinal stem cell markers. J Anat. 2008;213:52-8.

34. El-Salhy M, Hatlebakk JG, Hausken T. The reduction in duodenal endocrine cells in IBSis associated with stem cell abnormalities. World J Gastroenterol. 2015;21:9577-87.

35. El-Salhy M, Seim I, Chopin L, Gundersen D, Hatlebakk JG, Hausken T. Irritable bowel syndrome: the role of gut neuroendocrine peptides. Front Biosci (Elite Ed). 2012:4:2783-800.

36. El-Salhy M, Mazzawi T, Hausken T, Hatlebakk JG. Interaction between diet and gastrointestinal endocrine cells. Biomedical reports. 2016:4:651-6.

37. Longstreth GF, Thompson WG, Chey WD, Houghton LA, Mearin F, Spiller RC. Functional bowel disorders. Gastroenterology. 2006;130:1480-91.

38. Spiller R, Aziz Q, Creed F, Emmanuel A, Houghton L, Hungin P, Jones R, Kumar D, Rubin G, Trudgill N, et al. Guidelines on the irritable bowel syndrome: mechanisms and practical management. Gut. 2007;56:1770-98.

39. Cardoso WV, Lu J. Regulation of early lung morphogenesis: questions, facts and controversies. Development. 2006;133:1611-24.

40. Darlington GJ. Molecular mechanisms of liver development and differentiation. Curr Opin Cell Biol. 1999;11:678-82.

41. Fausto N, Campbell JS, Riehle KJ: Liver regeneration. Hepatology (Baltimore, Md). 2006:43:S45-53.

42. Rawlins EL, Hogan BL. Ciliated epithelial cell lifespan in the mouse trachea and lung. Am J Physiol Lung Cell Mol Physiol. 2008;295:L231-4.

43. Zaret KS. Regulatory phases of early liver development: paradigms of organogenesis. Nat Rev Genet. 2002;3:499-512.

44. Barker N, van Es JH, Kuipers J, Kujala P, van den Born M, Cozijnsen M, Haegebarth A, Korving J, Begthel H, Peters PJ, et al. Identification of stem cells in small intestine and colon by marker gene Lgr5. Nature. 2007;449:1003-7.

45. Barker $N$, van de Wetering $M$, Clevers $H$. The intestinal stem cell. Genes Dev. 2008:22:1856-64.

46. Barker N, Clevers $\mathrm{H}$. Tracking down the stem cells of the intestine: strategies to identify adult stem cells. Gastroenterology. 2007;133:1755-60.

47. Cheng $H$, Leblond CP. Origin, differentiation and renewal of the four main epithelial cell types in the mouse small intestine. V. Unitarian theory of the origin of the four epithelial cell types. Am J Anat. 1974;141:537-61.

48. Fontaine J, Le Lievre C, Le Douarin NM. What is the developmental fate of the neural crest cells which migrate into the pancreas in the avian embryo? Gen Comp Endocrinol. 1977;33:394-404.

49. Le Douarin NM, Teillet MA. The migration of neural crest cells to the wall of the digestive tract in avian embryo. J Embryol Exp Morphol. 1973;30:31-48.

50. Rawdon BB, Andrew A. Origin and differentiation of gut endocrine cells. Histol Histopathol. 1993:8:567-80.

51. Hoffman J, Kuhnert F, Davis CR, Kuo CJ: Wnts as essential growth factors for the adult small intestine and colon. Cell cycle (Georgetown, Tex) 2004:3:554-557.

52. Korinek V, Barker N, Moerer P, van Donselaar E, Huls G, Peters PJ, Clevers H. Depletion of epithelial stem-cell compartments in the small intestine of mice lacking Tcf-4. Nat Genet. 1998;19:379-83.

53. Potten CS, Booth C, Tudor GL, Booth D, Brady G, Hurley P, Ashton G, Clarke R, Sakakibara S, Okano H. Identification of a putative intestinal stem cell and early lineage marker; musashi-1. Differentiation. 2003;71(1):28-41.

54. Kayahara T, Sawada M, Takaishi S, Fukui H, Seno H, Fukuzawa H, Suzuki K, Hiai H, Kageyama R, Okano H, et al. Candidate markers for stem and early progenitor cells, Musashi-1 and Hes1, are expressed in crypt base columnar cells of mouse small intestine. FEBS Lett. 2003:535:131-5.

55. He XC, Yin T, Grindley JC, Tian Q, Sato T, Tao WA, Dirisina R, PorterWestpfahl KS, Hembree M, Johnson T, et al. PTEN-deficient intestinal stem cells initiate intestinal polyposis. Nat Genet. 2007;39:189-98.

56. Schonhoff SE, Giel-Moloney M, Leiter AB. Minireview: development and differentiation of gut endocrine cells. Endocrinology. 2004;145:2639-44.

57. Schonhoff SE, Giel-Moloney M, Leiter AB. Neurogenin 3-expressing progenitor cells in the gastrointestinal tract differentiate into both endocrine and non-endocrine cell types. Dev Biol. 2004;270:443-54.

58. Taupenot $\mathrm{L}$, Harper $\mathrm{KL}$, O'Connor DT. The chromogranin-secretogranin family. N Engl J Med. 2003;348:1134-49.

59. Wiedenmann B, Huttner WB. Synaptophysin and chromogranins/ secretogranins-widespread constituents of distinct types of neuroendocrine vesicles and new tools in tumor diagnosis. Virchows Arch B Cell Pathol Incl Mol Pathol. 1989;58:95-121. 
60. Deftos $L$. Chromogranin a: its role in endocrine function and as an endocrine and neuroendocrine tumor marker. Endocr Rev. 1991;12:181-7.

61. El-Salhy M, Wendelbo I, Gundersen D. Reduced chromogranin a cell density in the ileum of patients with irritable bowel syndrome. Mol Med Report. 2013;7:1241-4

62. Jenny M, Uhl C, Roche C, Duluc I, Guillermin V, Guillemot F, Jensen J, Kedinger M, Gradwohl G. Neurogenin3 is differentially required for endocrine cell fate specification in the intestinal and gastric epithelium. EMBO J. 2002;21:6338-47.

63. Spangeus A, Forsgren S, el-Salhy M. Does diabetic state affect colocalization of peptide $Y Y$ and enteroglucagon in colonic endocrine cells? Histol Histopathol. 2000;15:37-41.

64. Pyarokhil AH, Ishihara M, Sasaki M, Kitamura N. The developmental plasticity of colocalization pattern of peptide $Y Y$ and glucagon-like peptide- 1 in the endocrine cells of bovine rectum. Biomed Res. 2012;33:35-8.

65. Mortensen K, Christensen LL, Holst JJ, Orskov C. GLP-1 and GIP are colocalized in a subset of endocrine cells in the small intestine. Regul Pept. 2003;114:189-96.

66. Svendsen B, Holst JJ. Regulation of gut hormone secretion. Studies using isolated perfused intestines. Peptides. 2016;77:47-53.

67. Svendsen B, Pedersen J, Albrechtsen NJ, Hartmann B, Torang S, Rehfeld JF, Poulsen SS, Holst JJ. An analysis of cosecretion and coexpression of gut hormones from male rat proximal and distal small intestine. Endocrinology. 2015;156:847-57.

68. Egerod KL, Engelstoft MS, Grunddal KV, Nohr MK, Secher A, Sakata I, Pedersen J, Windelov JA, Fuchtbauer EM, Olsen J, et al. A major lineage of enteroendocrine cells coexpress CCK, secretin, GIP, GLP-1, PYY, and neurotensin but not somatostatin. Endocrinology. 2012;153:5782-95.

69. Maljaars PW, Keszthelyi D, Masclee AA. An ileal brake-through? Am J Clin Nutr. 2010;92:467-8.

70. Van Citters GW, Lin HC. Ileal brake: neuropeptidergic control of intestinal transit. Curr Gastroenterol Rep. 2006;8:367-73.

71. Lin HC, Zhao XT, Wang L, Wong H. Fat-induced ileal brake in the dog depends on peptide YY. Gastroenterology. 1996;110:1491-5.

72. Pironi L, Stanghellini V, Miglioli M, Corinaldesi R, De Giorgio R, Ruggeri E, Tosetti C, Poggioli G, Morselli Labate AM, Monetti N, et al. Fat-induced ileal brake in humans: a dose-dependent phenomenon correlated to the plasma levels of peptide YY. Gastroenterology. 1993;105:733-9.

73. Spiller RC, Trotman IF, Adrian TE, Bloom SR, Misiewicz JJ, Silk DB. Further characterisation of the 'ileal brake' reflex in man-effect of ileal infusion of partial digests of fat, protein, and starch on jejunal motility and release of neurotensin, enteroglucagon, and peptide YY. Gut. 1988;29:1042-51.

74. Spiller RC, Trotman IF, Higgins BE, Ghatei MA, Grimble GK, Lee YC, Bloom SR, Misiewicz JJ, Silk DB. The ileal brake-inhibition of jejunal motility after ileal fat perfusion in man. Gut. 1984;25:365-74.

75. Goumain M, Voisin T, Lorinet AM, Ducroc R, Tsocas A, Roze C, Rouet Benzineb P, Herzog H, Balasubramaniam A, Laburthe M. The peptide YYpreferring receptor mediating inhibition of small intestinal secretion is a peripheral Y(2) receptor: pharmacological evidence and molecular cloning. Mol Pharmacol. 2001:60:124-34.

76. Souli A, Chariot J, Voisin T, Presset O, Tsocas A, Balasubramaniam A, Laburthe M, Roze C. Several receptors mediate the antisecretory effect of peptide $Y Y$, neuropeptide $Y$, and pancreatic polypeptide on VIP-induced fluid secretion in the rat jejunum in vivo. Peptides. 1997;18:551-7.

77. Whang EE, Hines OJ, Reeve JR Jr, Grandt D, Moser JA, Bilchik AJ, Zinner MJ McFadden DW, Ashley SW. Antisecretory mechanisms of peptide YY in rat distal colon. Dig Dis Sci. 1997:42:1121-7.

78. El-Salhy M, Hausken T, Gilja OH, Hatlebakk JG. The possible role of gastrointestinal endocrine cells in the pathophysiology of irritable bowel syndrome. Expert Rev Gastroenterol Hepatol. 2017;11:139-48.

\section{Submit your next manuscript to BioMed Central and we will help you at every step:}

- We accept pre-submission inquiries

- Our selector tool helps you to find the most relevant journal

- We provide round the clock customer support

- Convenient online submission

- Thorough peer review

- Inclusion in PubMed and all major indexing services

- Maximum visibility for your research

Submit your manuscript at www.biomedcentral.com/submit
Biomed Central 